\title{
Lack of descriptive support results in no interference-in-fact
}

The Federal Circuit has agreed with the decision of the US PTO Board of Patent Appeals and Interferences, and decided that no interference-in-fact exists between Biogen's Lederman patent (US 5,474,771) and Idec's Noelle patent application claiming monoclonal antibodies specific for human CD40 ligand.

An interference is an administrative proceeding of the US PTO that determines priority of invention when two or more parties claim the same invention. To determine whether two parties claim the same invention, the patent office applies a two-way test. The test requires that the invention of party $A$ be the same as that of party $\mathrm{B}$, assuming $\mathrm{B}$ to be prior art to $\mathrm{A}$, and that the invention of party B be the same as that of party A, assuming A to be prior art to $B$. An invention is the same if it is anticipated by or would have been obvious over the presumptively earlier invention.

Applying its recent written-description jurisprudence for the first time to antibody claims, and further clarifying the workings of this two-way test for separate patentability, the court's decision upheld the validity of the claims in the Lederman patent.

Both parties had claimed monoclonal antibodies with specificity for CD40 ligand (CD40L). The Lederman claims were directed to antibodies specific for human CD40L, whereas Noelle claimed antibodies specific for murine CD40L, for human CD40L and for CD40L, in general.

However, Noelle's priority application had described only antibodies to the murine CD40L and methods of using CD40L-Ig fusion proteins to screen for $\mathrm{CD} 40 \mathrm{~L}$ antibodies. Applying its recent written-description jurisprudence to Noelle's antibody claims, the appeals court agreed with the US PTO Board that Noelle's description of antibodies to murine CD40L was insufficient to support Noelle's claims to antibodies to human CD40L or to CD40L in general.

The court also rejected Noelle's argument that the additional disclosure in his specification of methods of using CD40-Ig fusion proteins to screen for CD40L antibodies meant that Lederman's anti-human CD40L antibodies would have been obvious over Noelle's disclosure (if Noelle were presumed to be prior art to Lederman), and that the two were therefore the same invention for purpose of interference. Clarifying the application of the two-way test, the Federal Circuit maintained that only the claims of each party's application or patent were to be presumed to be prior art to the other party, which in this case meant that the claims to antimurine CD40L antibodies could not alone render obvious claims to the human antibody.

\section{Compensation for Japanese patent holders}

Japanese Patent Law stipulates that companies must pay innovators rewards "equivalent" to their achievements, and in a test on the rights of patent holders, the Tokyo District Court on Friday ruled that the Nichia Corporation must pay $¥ 20$ billion (US \$189 million) to Shuji Nakamura, the inventor of a widely used semiconductor device. When he worked for Nichia, Nakamura developed a revolutionary bluelight-emitting diode that has become a crucial part of flat-panel displays and other video screens. Nakamura left Nichia in 1999, having received only the equivalent of $\$ 189$, and later filed a suit demanding control of his patent. Having lost that challenge in 2002, when the courts decided that companies control the patents on research done in their laboratories, Nakamura then filed another suit demanding a share of the profits from his invention. This time, he was given the amount he requested, which represents the largest award ever in Japan. In a similar case, Hitachi Ltd was ordered to pay former employee Seiji Yonezawa ¥162.84 million
(US \$1.53 million) for his optical disk-related inventions. These victories will probably encourage other inventors to challenge their employers for control of their work. In future, companies might demand that employees sign more specific agreements about the sharing of profits from inventions.

\section{Double attack on patent for Wellbutrin sustained- release agent}

The US Court of Appeals for the Federal Circuit in Washington DC has ruled in favour of one generic company but against another in an infringement case concerning GSK's US patent $5,427,798$ for the sustainedrelease agent hydroxypropylmethylcellulose (HPMC) associated with bupropion hydrochloride. GSK markets controlled sustainedrelease tablets of bupropion hydrochloride as Wellbutrin SR for the treatment of depression and as Zyban for smoking cessation. The cases began when Impax Laboratories and Excel Pharmaceuticals filed Abbreviated New Drug Applications with the US FDA to make generic versions of both drugs, using a different sustained-release agent - hydroxypropyl cellulose (HPC) and polyvinyl alcohol (PVA), respectively — in their formulations. Neither of these agents is claimed in GSK's patent, so the case hinged on using the doctrine of equivalents to prove infringement of its patent. During prosecution of its patent, GSK had amended many of its claims to overcome a rejection for lack of enablement because the claims improperly embraced a genus of sustained-release agents, and they explicitly claimed its sustained-release agent HPMC. According to the Festo ruling, the scope of the claim becomes limited unless the patentee can show that the alleged equivalent could not reasonably have been described at the time the amendment was made. Although it was not clear whether HPC could have been described at the time of filing, Judge Rader found that there was abundant evidence for the use of HPC as a release agent at the time of the amendment, and therefore the court rejected GSK's rebuttal of the Festo presumption. However, the judge found that the record for PVA does not permit a similar finding. GW versus Impax:

htpp://www.fedcir.gov/opinions/02-1581.doc SKB versus Excel:

htpp://www.fedcir.gov/opinions/03-1013.doc 